\title{
Effect of Analgesics on Monoclonal Antibody Ascites Production in Mice Administered Upon Recognition of Pain
}

\author{
Shannon T. Marko, ${ }^{1}$ Stephen F. Little, ${ }^{2}$ Carrie G. Benton, ${ }^{1}$ \\ Richard Kelly III, ${ }^{1}$ Amy E. Field, ${ }^{1}$ and Rachel S. Laufer ${ }^{2}$ \\ ${ }^{1}$ Veterinary Medicine Division, United States Army Medical Research Institute for Infectious Diseases, Fort Detrick, MD 21702, USA \\ ${ }^{2}$ Bacteriology Division, United States Army Medical Research Institute for Infectious Diseases, Fort Detrick, MD 21702, USA
}

Correspondence should be addressed to Shannon T. Marko; shannon.marko@us.army.mil and Stephen F. Little; stephen.f.little.civ@mail.mil

Received 11 October 2013; Accepted 18 November 2013; Published 11 March 2014

Academic Editors: A. Sundstedt and A. Taylor-Robinson

Copyright (C) 2014 Shannon T. Marko et al. This is an open access article distributed under the Creative Commons Attribution License, which permits unrestricted use, distribution, and reproduction in any medium, provided the original work is properly cited.

\begin{abstract}
Monoclonal antibody $(\mathrm{mAb})$ ascites fluid production in mice is a well described method of antibody production, although ethical questions regarding the pain and distress of the animals utilized in this process have been raised. In this study, mice were injected with pristane to initiate granuloma formation, followed by an injection of murine hybridoma PA 2II 2F9-1-1 (2F9) to produce IgG1 subclass $\mathrm{mAb}$ directed against protective antigen (PA) protein of Bacillus anthracis. Upon the recognition of pain or distress, characterized by well accepted clinical signs, analgesics were administered by treatment group. The control group (A) received saline, group (B) received meloxicam, group (C) received buprenorphine, and group (D) received both meloxicam and buprenorphine. Analgesics were administered by group for a total of 36-48 hours prior to the second ascites fluid collection. There was no statistical difference in the antibody titer or functionality $(P>0.05)$ between treatment groups at the first or the second collection time points. As reported here, analgesics may be administered upon recognition of pain in mice used for mAb ascites fluid production without affecting antibody concentration or quality and may warrant further evaluation as a refinement in other hybridoma cell lines.
\end{abstract}

\section{Introduction}

Monoclonal antibody $(\mathrm{mAb})$ ascites fluid production in mice is a well described method of antibody production [1-3]. $\mathrm{mAb}$ ascites fluid is typically produced in mice that are induced to form granulomas by intraperitoneal injection of pristane about fourteen days before injecting the hybridoma cell line. Pristane prevents the removal of hybridoma cells from the peritoneal cavity to the peripheral circulation, allowing growth of the hybridoma cells and the accumulation of ascites fluid containing the desired antibody $[4,5]$. Ascites production is affected by several factors including the hybridoma cell line, timing of pristane injection in relation to inoculation of the hybridoma cells, and the age of mice $[1,6,7]$. The volume of pristane injected, the number of hybridoma cells injected, the frequency and method of abdominal paracentesis, and the hybridoma growth characteristics may all influence pain, distress, and survival $[1,6,7]$.
Based upon observed clinical, pathophysiological, and pathological findings, the production of ascites is considered to cause pain and distress in mice [3,6-8]. The injection of pristane induces a chronic inflammatory response in the development of granulomatous tissue and is not considered to cause pain in the short term $[1,8]$. However, the in vivo growth of the hybridoma tumor with the resulting production of ascites fluid is considered to cause pain and distress as determined by the presence of clinical signs $[1,8]$. It is recommended that efforts be made to minimize pain and distress of mice utilized for $\mathrm{mAb}$ production by conducting frequent observations, limiting the number of ascites collections, performing euthanasia if the signs of distress are persistent, and utilizing in vitro methods whenever possible [1].

Ethical concerns regarding in vivo ascites production have led to the development of in vitro $\mathrm{mAb}$ production methods [9]. There are various methods to produce $\mathrm{mAb}$ in 
vitro; however not all cell lines produce the required quantity or quality of antibodies as compared to the in vivo ascites method $[1,9]$. Due to the pain and distress of $\mathrm{mAb}$ production in mice, it is recommended that in vitro methods are utilized and that if in vivo methods are required then they are scientifically justified [1]. Our facility has provided ascites fluid from several hybridomas which are used to characterize the production of anthrax vaccine adsorbed (AVA BioThrax). Additionally, specific antibody Fab (fragment antigen binding) fragments were needed for other experiments but were not able to be derived from $\mathrm{mAbs}$ prepared in vitro. Therefore in vivo methods were employed.

In order to address the potential pain and distress caused by ascites production, our IACUC questioned if analgesics given upon the recognition of pain in mice used for $\mathrm{mAb}$ ascites production would affect the quantity or quality of antibodies produced. Preemptive analgesia was not considered because it was assumed from previous research that it would negatively impact the antibody production by inhibiting the immune system as opioids and nonsteroidal antiinflammatories (NSAIDs) that analgesics are reported to do [10-15]. Indomethacin, an NSAID, inhibited the development of plasma cell tumors in mice injected with pristane [10] possibly by inhibiting IL-6 [15]. Additionally indomethacin was reported to decrease $\mathrm{mAb}$ antibody ascites fluid production in mice [14]. Opiate analgesics have also been reported to alter the outcome of immunological experiments [11, 13]. However, a recent study showed that there was no effect on antibody response when using the analgesics acetaminophen, meloxicam, and buprenorphine at standard doses when given to mice that were immunized [16]. Additionally, using a panel of various behavior tests, it was also shown that the analgesics were effective in alleviating the pain caused by immunization when used at standard published doses [16, 17].

The effect of analgesics on alleviating pain during the development of the pristane-induced granulomas, the growth of the hybridomas, and the ascites fluid quality has not been thoroughly studied. Meloxicam, buprenorphine and a combination of the two (multimodal analgesia) are commonly used analgesics and have not been evaluated in mice used for $\mathrm{mAb}$ ascites fluid production. The objective of this study was to compare the yields and quality of mAbs produced in ascites fluid between mice given these analgesics and mice not given analgesics upon the recognition of pain. The hypothesis was that analgesics used would decrease the quantity and quality of $\mathrm{mAbs}$ produced by altering the host immune response.

\section{Materials and Methods}

2.1. Animals. Forty-eight male (6-8 weeks old) BALB/c mice (Mus musculus) were purchased from Charles River (Kingston, NY). Vendor health reports verified that mice were free of epizootic diarrhea of infant mice, mouse hepatitis virus, mouse parvovirus, minute virus of mice, Theiler murine encephalomyelitis virus, Mycoplasma pulmonis, ectromelia virus, pneumonia virus of mice, Sendai virus, fur mites, and pinworms. Upon arrival mice were housed in groups of 6 in standard polycarbonate cages with filter tops on alpha-dry bedding (Alph-Dri, Sheperd Specialty Papers, Portage, MI). Cotton nest pads (Nestlets, Ancare Corporation, Bellmore, $\mathrm{NY}$ ) were provided in each cage for enrichment and to aid in thermoregulation. Standard pelleted rodent diet (7022, Harlan Laboratories, Indianapolis, IN) and bottled tap water were provided ad libitum. Ambient room temperature was maintained at $68-79^{\circ} \mathrm{F}$ and relative humidity of $30-70 \%$. Light cycles were set at $12 \mathrm{~h}$ on (0600 to 1800$)$ and $12 \mathrm{~h}$ off (1800 to 0600) for the entire study period. Research was conducted under an IACUC approved protocol in compliance with the Animal Welfare Act, PHS Policy, and other Federal statutes and regulations relating to animals and experiments involving animals. The facility where this research was conducted is accredited by the Association for Assessment and Accreditation of Laboratory Animal Care International and adheres to the principles stated in the 8th Edition of the Guide for the Care and Use of Laboratory Animals, National Research Council, 2011.

2.2. Experimental Design. Forty-eight mice were split into four treatment groups (A, B, C, and D) of 12 mice each. Each group was housed in two separate cages (A1, A2, B1, etc.) of 6 mice each. Each group was used for antibody ascites production as described below. After the hybridoma cells were injected in mice, animals in each cage were examined and scored using Table 1 that incorporates consistently reported clinical signs as indicators of pain and distress $[12,18]$ and implements observation frequency and interventions based on the total score. Each animal was scored individually, but groups were given a cage score based on the animal with the highest score (worst condition). After any animal in a cage scored $\geq 2$, as agreed upon by 4 trained observers, treatment with analgesics was initiated for all animals in that cage. All injections were of a volume of $0.1 \mathrm{~mL}$ and given subcutaneously between the shoulders as described in Table 2. Group A served as the control group and received $0.9 \% \mathrm{NaCl}$ (Hospira Inc., Lake Forrest, IL) administered twice daily $(12 \pm 2 \mathrm{~h})$. Group B received $2 \mathrm{mg} / \mathrm{kg}$ meloxicam, Metacam (Boehringer Ingelheim, St. Joseph, MO), which was administered once daily $(24 \pm 2 \mathrm{~h})$ and $0.9 \% \mathrm{NaCl}$ $(12 \pm 2 \mathrm{~h})$ after the meloxicam was administered once daily. Group C received $0.1 \mathrm{mg} / \mathrm{kg}$ buprenorphine hydrochloride, Buprenex (Reckitt Benckiser Pharmaceuticals, Richmond VA), which was administered twice daily $(12 \pm 2 \mathrm{~h})$. Group D received both $2 \mathrm{mg} / \mathrm{kg}$ meloxicam once daily and $0.1 \mathrm{mg} / \mathrm{kg}$ burprenorphine twice daily. Mice were anesthetized with an intramuscular injection $(0.1 \mathrm{~mL}$ per $20 \mathrm{~g}$ body weight $)$ of a ketamine $(9 \mathrm{mg} / \mathrm{mL})$-acepromazine $(0.9 \mathrm{mg} / \mathrm{mL})$-xylazine $(1.8 \mathrm{mg} / \mathrm{mL})$ solution prior to ascites collection and prior to euthanasia by cervical dislocation.

2.3. Hybridoma Cell Line. Murine hybridoma PA 2II 2F9-11 (2F9) producing IgG1 subclass $\mathrm{mAb}$ has been previously described [19]. It is directed against protective antigen (PA), a component of the Bacillus anthracis lethal toxin. MAb 2F9 has been reported to enhance the in vitro cytotoxicity and in vivo toxicity of $B$. anthracis lethal toxin $[20,21]$. MAb $2 \mathrm{~F} 9$ hybridoma cells were collected in logarithmic growth from 
TABLE 1: Intervention scoresheet for mice used for $\mathrm{mAb}$ ascites production.

\begin{tabular}{|c|c|c|}
\hline Parameter & Observation & Score \\
\hline \multirow{5}{*}{ Appearance } & Normal (coats smooth, eyes/nose clear) & 0 \\
\hline & Reduced grooming & 1 \\
\hline & Dull/rough coat, ocular/nasal discharge & 2 \\
\hline & Absence of grooming, piloerection, hunched up & 3 \\
\hline & Normal & 0 \\
\hline \multirow{2}{*}{ Natural behavior } & Minor changes, less peer interaction & 1 \\
\hline & Little peer interaction, less mobile and alert, isolated & 2 \\
\hline \multirow{6}{*}{ Provoked behavior } & No peer interaction, vocalization, self-mutilation, restless or still & 3 \\
\hline & Normal & 0 \\
\hline & Subdued but normal when stimulated & 1 \\
\hline & Subdued even when stimulated & 2 \\
\hline & Unresponsive when stimulated, weak, precomatose & 3 \\
\hline & Total & 0-9 \\
\hline Total score & Observation frequency or intervention & \\
\hline 0 & Daily observation (1X) & \\
\hline $1-2$ & Observation $2 \mathrm{X}$ daily, at least 4 hours apart & \\
\hline$\geq 2$ & Start treatment according to group & \\
\hline $3-7$ & Observation $3 \mathrm{X}$ daily, at least 4 hours apart & \\
\hline $8-9$ & Euthanize & \\
\hline
\end{tabular}

TABLE 2: Analgesic treatment plan by group.

\begin{tabular}{llc}
\hline Group & Treatments $^{\mathrm{a}}$ and frequency & Dose \\
\hline A: Control & $0.9 \% \mathrm{NaCl}$ every $12 \pm 2 \mathrm{hr}$ & $\mathrm{n} / \mathrm{a}$ \\
\hline B: NSAID & Meloxicam every $24 \pm 2 \mathrm{hr}$ and $0.9 \% \mathrm{NaCl} 12$ hours after meloxicam & $2 \mathrm{mg} / \mathrm{kg}$ and $\mathrm{n} / \mathrm{a}$, respectively \\
\hline C: Opioid & Buprenorphine every $12 \pm 2 \mathrm{hr}$ & $0.1 \mathrm{mg} / \mathrm{kg}$ \\
\hline D: NSAID and opioid & Meloxicam every $24 \pm 2 \mathrm{hr}$ and buprenorphine every $12 \pm 2 \mathrm{hr}$ & 2 and $0.1 \mathrm{mg} / \mathrm{kg}$, respectively \\
\hline
\end{tabular}

${ }^{a}$ All treatments were given subcutaneously upon recognition of clinical signs (Table 1).

T-150 cell culture flasks, washed in Dulbecco's phosphate buffered saline, and adjusted to $6.4 \times 10^{6}$ cells per $\mathrm{mL}$.

2.4. Monoclonal Antibody Ascites Production. BALB/c mice were given a single $0.2 \mathrm{~mL}$ intraperitoneal (IP) injection of pristane (Sigma Chemical Co., St. Louis, MO). Fourteen days later, mice were injected with a single IP injection of $3.2 \times$ $10^{6}$ in a volume of $0.5 \mathrm{~mL}$ of the hybridoma cells described above, after which they were examined daily for development of ascites fluid recognized by abdominal distention.

Five days after the injection of hybridoma cells, moderate abdominal distention was noted in all groups of mice and at least one mouse in groups A1, A2, B1, B2, C1, C2, and D1 scored $\geq 2$ on the intervention scoresheet. Based on these scores and the recognition of abdominal distention, mice were anesthetized and the first collection of ascites fluid was performed on all mice in all groups. Ascites fluid was collected aseptically from anesthetized mice by abdominal paracentesis with an 18-22 gauge needle by gravity flow into sterile centrifuge tubes. Digital pressure was gently applied to the abdomen and the position of the mouse was altered as needed to facilitate removal of the ascites fluid. Ascites was pooled for each separate cage of mice.
After mice had recovered from anesthesia, all groups received DietGel Recovery (Clear $\mathrm{H}_{2} \mathrm{O}$, Portland ME) in their cages for the remainder of the experiment and the administration of analgesics was initiated for all the mice based upon the scoring conducted immediately prior to the ascites collection. Group D2, did not score $\geq 2$ on day 5 , but did 12 hours later on day 6 , in which analgesics were initiated. All groups continued with their respective analgesic/saline regimens until the end of the study as shown in Table 3.

On day 4, prior to the first ascites collection, one mouse from group $\mathrm{Cl}$ was found dead (no analgesics had been given; no mice showed any abnormalities the night before). A mouse from cage B2 was noted to have difficulty breathing prior to anesthesia and died under sedation during the first ascites collection (no analgesics had been given; significant ascites was present). A mouse in group B2 (meloxicam) and a mouse in C1 (buprenorphine) were found dead on the morning of the seventh day prior to the second ascites collection after they had been given their respective analgesics for 24 hours. These losses are reflected in Table 4. Although the effect of each hybridoma cell line varies in mice, the number of deaths reported are within normal limits for this procedure [7].

All groups of mice had the second and final collection of ascites fluid on the evening of the seventh day after the initial 
TABLE 3: Analgesic treatments given upon recognition of clinical signs.

\begin{tabular}{|c|c|c|c|c|c|c|c|c|c|c|}
\hline \multirow{3}{*}{ Group } & \multirow{3}{*}{ Cage ID } & \multirow{3}{*}{ Treatments given } & \multicolumn{8}{|c|}{ Treatments given on days after hybridoma cell injections $\mathrm{s}^{\mathrm{a}}$} \\
\hline & & & \multicolumn{2}{|c|}{$0-4^{\mathrm{b}}$} & \multicolumn{2}{|c|}{5} & \multicolumn{2}{|c|}{6} & \multicolumn{2}{|c|}{7} \\
\hline & & & $\mathrm{AM}$ & PM & $\mathrm{AM}$ & $\mathrm{PM}^{\mathrm{c}}$ & AM & PM & $\mathrm{AM}$ & $\mathrm{PM}^{\mathrm{d}}$ \\
\hline A & $\mathrm{A} 1, \mathrm{~A} 2$ & $0.9 \%$ saline & - & - & - & + & + & + & + & - \\
\hline \multirow{2}{*}{ B } & \multirow{2}{*}{$\mathrm{B} 1, \mathrm{~B} 2$} & Meloxicam & - & - & - & + & - & + & - & - \\
\hline & & Saline & - & - & - & - & + & - & + & - \\
\hline \multirow{2}{*}{$\mathrm{C}$} & \multirow{2}{*}{$\mathrm{C} 1, \mathrm{C} 2$} & Buprenorphine & - & - & - & + & + & + & + & - \\
\hline & & Buprenorphine & - & - & - & + & + & + & + & - \\
\hline \multirow{4}{*}{$\mathrm{D}$} & \multirow{2}{*}{ D1 } & Meloxicam & - & - & - & + & - & + & - & - \\
\hline & & Buprenorphine & - & - & - & + & + & + & + & - \\
\hline & \multirow{2}{*}{ D2 } & Meloxicam & - & - & - & - & + & - & + & - \\
\hline & & Buprenorphine & - & - & - & - & + & + & + & - \\
\hline
\end{tabular}

${ }^{\mathrm{a}}$ Treatments denoted with - indicate that the treatment was not given and + indicates that the treatment was given. ${ }^{\mathrm{b}}$ Hybridoma cells were injected on day 0 . ${ }^{\mathrm{c}}$ The treatments were given after the first ascites fluid collection conducted on the evening of Day $5 .{ }^{\mathrm{d}}$ All mice were euthanized, prior to the second and final ascites fluid collection on the evening of day 7.

hybridoma cells were injected. Analgesics were administered to all mice in groups B, C, and D for 24-36 hours prior to euthanasia. It was decided during the evening observation on the seventh day of the study that all mice were still under some distress and that abdominal distention was evident; a score of 3-7 was observed in all mice, and therefore euthanasia was elected. Ascites was collected immediately after the mice were anesthetized and euthanized and pooled for each separate cage.

2.5. Antibody Quantitation. An indirect antibody ELISA was used to quantitatively screen the antibody in each ascites sample as previously described [22]. Briefly, Immulon $2 \mathrm{HB}$ 96-well microtiter plates were coated overnight at $4^{\circ} \mathrm{C}$ with B. anthracis PA at $100 \mathrm{ng} /$ well. After washing the plates, standards and samples were diluted in PBS, 0.5\% Tween 20, and 5\% nonfat dry milk and added in triplicate and the plates were incubated at $37^{\circ} \mathrm{C}$ for 1 hour. Plates were sequentially incubated with horseradish peroxidase conjugated goat antimouse IgG $(\gamma)$ for $1 \mathrm{~h}$ and ABTS substrate (KPL, Gaithersburg, MD) for $30 \mathrm{~min}$. Plates were washed with PBS containing $0.1 \%$ Tween 20 between steps. Absorbance values were collected and titers quantified from the standard curve using the plate reading software Gen 5 (BioTek Instruments, Winooski, VT). The ELISA was performed three times.

2.6. Enhancement of Lethal Toxin Cytotoxicity. Antibody dependent enhancement (ADE) activity of $B$. anthracis lethal toxin in vitro cytotoxicity by mAb $2 \mathrm{~F} 9$ was examined by using the J774A.1 murine macrophage cell line as described [21]. Briefly, J774A.1 seeded cell-culture 96-well plates were incubated with serial dilutions of mAb $2 \mathrm{~F} 9$ to which was added an equal volume of a fixed concentration of lethal toxin that would be cytotoxic for approximately $10-30 \%$ of the cells $(20 \mathrm{ng}$ of protective antigen per $\mathrm{mL}$ and $10 \mathrm{ng}$ lethal factor per $\mathrm{mL}$ ). Wells that contained only lethal toxin served as toxin controls and wells with only medium served as medium controls. After incubating ascites and lethal toxin on the J774A.1 cells for $4 \mathrm{~h}$ at $37^{\circ} \mathrm{C}, 5 \% \mathrm{CO}_{2}, 25 \mu \mathrm{L}$ of 3-[4,5-dimethylthiazol-2-yl]2,5-diphenyltetrazolium bromide (MTT; Sigma), and $5 \mathrm{mg} / \mathrm{mL}$ of PBS were added to each well and the plates incubated for $2 \mathrm{~h}$. The cells were lysed and the precipitate was solubilized by adding $100 \mu \mathrm{L}$ per well of $10 \%$ SDS in $50 \%$ dimethylformamide, $\mathrm{pH}$ 4.8. Absorbance readings were read at $570 \mathrm{~nm}$ with a $690 \mathrm{~nm}$ reference filter. The percent viability, determined by dividing the sample absorbance values by the medium control absorbance values, was then plotted against the log dilution of the sample using XLfit software (IDBS, Emeryville, CA). The anti-PA IgG concentration of the dilution whose percent viability corresponded to the midpoint of each 4-parameter titration curve was then calculated using XLfit. Each sample was tested in triplicate in two assays.

2.7. Statistical Analysis. Linear mixed models were fit for each titer measurement method with fixed effects of group (A, B, $\mathrm{C}$, and $\mathrm{D}$ ), date of ascites collection, and their interaction, along with a repeated effect to account for repeated measurements. Comparisons were made to contrast the titers of each pair of groups at each measurement date and to contrast the titers at the two measurement dates for each group. All $P$ values are two-sided and were adjusted by simulation to account for multiple comparisons. Adjusted $P$ values are considered significant at the $\alpha=0.05$ level.

\section{Results}

3.1. Ascites Fluid Volumes and Anti-PA IgG ELISA Titers. Mice in all groups received no treatments prior to the first collection of ascites conducted five days after hybridoma cells were injected, based on mice scoring $<2$ on the intervention score sheet as agreed on by four observers. From the first ascites collection, volumes ranged from $7.0 \mathrm{~mL}$ to $12.5 \mathrm{~mL}$ for 5-6 mice per group or 1.2 to $2.1 \mathrm{~mL}$ per mouse. Anti-PA IgG ELISA titers ranged from 4.8 to $9.8 \mathrm{mg} \mathrm{IgG} / \mathrm{mL}$ for each group (Table 4 ) and the average ELISA titers were not statistically 
TABLE 4: mAb 2F9 ascites volumes, ELISA titers, and ADE titers at midpoint for treatment groups.

\begin{tabular}{|c|c|c|c|c|c|c|c|c|c|}
\hline Group, Cage ID & $\begin{array}{l}\text { Tap } \\
\text { no. }\end{array}$ & $\begin{array}{l}\text { No. } \\
\text { mice }\end{array}$ & $\begin{array}{l}\text { Total } \\
\text { vol. } \\
(\mathrm{mL})\end{array}$ & $\begin{array}{l}\text { Volume } \\
\mathrm{mL} / \text { mouse }\end{array}$ & $\begin{array}{c}\text { Ab conc. } \\
(\mathrm{mg} \operatorname{IgG} / \mathrm{mL})^{\mathrm{a}}\end{array}$ & $\begin{array}{l}\text { Avg Ab conc. } \\
(\mathrm{mg} \operatorname{IgG} / \mathrm{mL})^{\mathrm{b}}\end{array}$ & $\begin{array}{c}\text { ADE titer } \\
(\text { ng } \operatorname{IgG} / \mathrm{mL})^{\mathrm{c}}\end{array}$ & $\begin{array}{l}\text { Avg ADE titer } \\
(\text { ng } \operatorname{IgG} / \mathrm{mL})^{\mathrm{d}}\end{array}$ & $\mathrm{ADE} / \operatorname{IgG}^{\mathrm{e}}$ \\
\hline \multicolumn{10}{|l|}{ A saline } \\
\hline A1 & 1 & 6 & 8.5 & 1.4 & $8.6 \pm 1.96$ & \multirow{2}{*}{$6.7 \pm 2.46$} & 152.9 & \multirow{2}{*}{150.8} & \multirow{2}{*}{22.4} \\
\hline $\mathrm{A} 2$ & 1 & 6 & 7.0 & 1.2 & $4.8 \pm 0.40$ & & 148.8 & & \\
\hline $\mathrm{A} 1$ & 2 & 6 & 11.0 & 1.8 & $26.5 \pm 4.08$ & \multirow{2}{*}{$23.6 \pm 4.36$} & 185.1 & \multirow{2}{*}{176.4} & \multirow{2}{*}{7.5} \\
\hline $\mathrm{A} 2$ & 2 & 6 & 12.5 & 2.1 & $20.7 \pm 2.41$ & & 167.7 & & \\
\hline \multicolumn{10}{|l|}{ B meloxicam } \\
\hline $\mathrm{B} 1$ & 1 & 6 & 10.0 & 1.7 & $8.0 \pm 1.75$ & \multirow{2}{*}{$8.1 \pm 1.23$} & 162.7 & \multirow{2}{*}{169.7} & \multirow{2}{*}{20.9} \\
\hline B2 & 1 & $5^{\mathrm{f}}$ & 9.5 & 1.9 & $8.2 \pm 0.82$ & & 176.8 & & \\
\hline $\mathrm{B} 1$ & 2 & 6 & 8.5 & 1.4 & $32.1 \pm 4.14$ & \multirow{2}{*}{$33.2 \pm 4.79$} & 201.0 & \multirow{2}{*}{185.9} & \multirow{2}{*}{5.6} \\
\hline $\mathrm{B} 2$ & 2 & $4^{\mathrm{g}}$ & 6.5 & 1.6 & $34.2 \pm 6.07$ & & 170.8 & & \\
\hline \multicolumn{10}{|l|}{ C buprenorphine } \\
\hline $\mathrm{Cl}$ & 1 & $5^{\mathrm{h}}$ & 7.5 & 1.5 & $9.2 \pm 5.11$ & \multirow{2}{*}{$8.5 \pm 3.73$} & 273.3 & \multirow{2}{*}{242.9} & \multirow{2}{*}{28.7} \\
\hline $\mathrm{C} 2$ & 1 & 6 & 10.5 & 1.8 & $7.7 \pm 2.66$ & & 212.5 & & \\
\hline $\mathrm{Cl}$ & 2 & $4^{\mathrm{i}}$ & 4.5 & 1.1 & $29.5 \pm 5.23$ & \multirow{2}{*}{$26.7 \pm 5.15$} & 208.5 & \multirow{2}{*}{226.2} & \multirow{2}{*}{8.5} \\
\hline $\mathrm{C} 2$ & 2 & 6 & 10.0 & 1.7 & $23.8 \pm 3.81$ & & 243.9 & & \\
\hline \multicolumn{10}{|l|}{$\begin{array}{l}\text { D meloxicam + } \\
\text { buprenorphine }\end{array}$} \\
\hline D1 & 1 & 6 & 12.5 & 2.1 & $9.8 \pm 0.40$ & \multirow[t]{2}{*}{$7.8 \pm 2.23$} & 179.4 & \multirow[t]{2}{*}{173.3} & \multirow[t]{2}{*}{22.2} \\
\hline D2 & 1 & 6 & 12.0 & 2.0 & $5.8 \pm 0.41$ & & 167.2 & & \\
\hline D1 & 2 & 6 & 5.0 & 0.8 & $37.1 \pm 7.76$ & \multirow{2}{*}{$31.0 \pm 8.60$} & 191.6 & \multirow{2}{*}{173.2} & \multirow{2}{*}{5.6} \\
\hline D2 & 2 & 6 & 7.0 & 1.2 & $24.8 \pm 3.54$ & & 154.8 & & \\
\hline
\end{tabular}

${ }^{a}$ Average anti-PA IgG ELISA titer and standard deviation for each collection (tap number) from three ELISAs. ${ }^{\mathrm{b}}$ Average ELISA titer and standard deviation for the first or second collection of ascites for each test group. ${ }^{\mathrm{c}}$ Average ADE titer for each cage by collection (tap number) from two assays. ${ }^{\mathrm{d}}$ Average ADE titer for the first and second collection of ascites for each test group. ${ }^{e}$ Ratio between ADE titer and respective anti-PA IgG ELISA titer. ${ }^{\mathrm{f}} 1$ mouse succumbed while anesthetized after first paracentesis on day $5 .{ }^{\mathrm{g}} 1$ mouse succumbed on day 7 prior to the second ascites collection. ${ }^{\mathrm{h}} 1$ mouse succumbed on day 4 before initial paracentesis. ${ }^{i} 1$ mouse succumbed on day 7 prior to the second ascites collection.

different between groups for the first ascites collection $(P>$ 0.05).

After the first ascites fluid collection the mice received analgesics by treatment group for 36-48 hours prior to the second and final ascites collection. Volumes of ascites fluid ranged from $4.5 \mathrm{~mL}$ to $12.5 \mathrm{~mL}$ for 4 or 6 mice per group or 0.8 to $2.1 \mathrm{~mL}$ per mouse from the final collection. The anti-PA IgG ELISA titers ranged from 20.7 to $37.1 \mathrm{mg} \mathrm{IgG} / \mathrm{mL}$ (Table 4). The quantitative anti-PA IgG ELISA titers from the second collection of ascites were $23.6 \pm 4.36 \mathrm{mg}$ IgG per $\mathrm{mL}$ from the control group, $33.2 \pm 4.79 \mathrm{mg}$ IgG per $\mathrm{mL}$ from the meloxicam group, $26.7 \pm 5.15 \mathrm{mg} \operatorname{IgG}$ per $\mathrm{mL}$ from the buprenorphine group, and $31.0 \pm 8.60 \mathrm{mg}$ IgG per $\mathrm{mL}$ from the meloxicambuprenorphine group (Table 4). No significant differences in ELISA titers between groups from the final collection of ascites was observed $(P>0.05)$. However, there was an overall significant difference $(P<0.0001)$ between the first and second ascites collections for all groups: group $\mathrm{A}(P=$ $0.0012)$, group $\mathrm{B}(P=0.0007)$, group $\mathrm{C}(P=0.0015)$, and group $\mathrm{D}(P=0.0008)$.

3.2. Functional Activity of $m A b 2 F 9$. The functional activity of $\mathrm{mAb} 2 \mathrm{~F} 9$ was examined by exploiting the ability of $\mathrm{mAb}$
2F9 to cause an increase in B. anthracis lethal toxin cytoxicity resulting in a decrease in viability of J774A.1 cells as described in the methods. J774A.1 cells were incubated with a concentration of lethal toxin that resulted in a percent viability of about $70-90 \%$ (lethal toxin control wells) compared to wells without lethal toxin (media control wells). In the presence of $\mathrm{mAb} 2 \mathrm{~F} 9$, the percent viability of J774A.1 cells exposed to lethal toxin was reduced to about $20-30 \%$ (data not shown). ADE group midpoint titers of ascites from the first paracentesis ranged from 150.8 to $242.9 \mathrm{ng}$ of $\mathrm{IgG}$ per $\mathrm{mL}$. (Table 4). The average midpoint titer from each group was not statistically different between groups $(P>0.05)$.

For 36-48 hours prior to the second and final ascites fluid collection mice received analgesics. From the second ascites collection, ADE midpoint titers ranged from 173.2 to $226.2 \mathrm{ng}$ of IgG per $\mathrm{mL}$. The average of the ADE titers from the second collection of ascites for each group was $176.4 \mathrm{ng}$ IgG per $\mathrm{mL}$ from the control group, $185.9 \mathrm{ng}$ IgG per $\mathrm{mL}$ from the meloxicam group, $226.2 \mathrm{ng}$ IgG per $\mathrm{mL}$ from the buprenorphine group, and $173.2 \mathrm{ng} \operatorname{IgG}$ per $\mathrm{mL}$ from the meloxicam-buprenorphine group (Table 4). The difference in average $\mathrm{ADE}$ midpoint titers between groups was not significant $(P>0.05)$. 
The differences between the average ADE midpoint titers between the first and second collection of ascites fluid for each group were not significant $(P>0.05)$ as that there was only a 0.9 -fold to 1.2 -fold increase in the average IgG concentration. However, a comparison between the average ADE midpoint titers with the respective anti-PA IgG titers for each date and from each group showed that ADE activity per mg of antiPA IgG decreased from the first ascites collection between 20.9 and $28.7 \mathrm{ng}$ per mg anti-PA IgG to the second collection between 5.6 and 8.5 ng per mg anti-PA IgG (Table 4).

\section{Discussion}

The preparation of ascites fluid in mice has raised ethical considerations regarding pain and distress. In this study, we were interested in determining if pain control measures initiated upon recognition of clinical signs of pain and distress during preparation of ascites fluids would have an impact on the antibody titer, either specific IgG concentration or functional activity. We were able to determine that pain control measures did not have an adverse effect on the development of the volume of ascites fluid collected, the antibody titer nor the quality of the antibody collected after 36-48 hours of treatment. Normally, individual collections of ascites are subsequently pooled before analysis unless the study is directed toward examining production parameters such as volume of ascites produced or titer over time $[2,6,23]$. We noted a significant increase in antibody concentration (anti-PA IgG) between the first and second ascites collections. This finding supports that $\mathrm{mAb}$ ascites fluid composition can vary between hybridoma cells lines and may vary between collections [6].

Our study was unique in that we examined the functional activity of antibody in ascites for each collection time point in addition to the volume and antibody titer. Although we observed no significant difference in ADE titer between the first and second ascites fluid collection, there was a 3- to 4fold decrease in ADE activity per mg of anti-PA IgG from the first to the second collection of ascites for all groups. This finding has not been reported in the literature. While we have prepared mAbs from several hybridomas both from ascites fluid and in vitro using CELLine brand CL1000 membrane based flasks, we have only examined ELISA and functional activity titers of pooled ascites and culture supernatants and not individual collections to examine if differences in titer occur over time as they did in this study. This finding should be investigated further and warrants some analysis of what the antibody collected will be used for. If functionality is paramount, then it would be recommended that analysis be performed after each collection time frame to ensure that it is maintained and to optimize the ascites fluid collection schedule.

The consensus has been that certain analgesics have an effect on depressing the immune response in animal studies. Two clinical studies investigating pain management concluded that over-the-counter NSAIDs depress the antibody response to vaccination $[24,25]$. However, a study in mice using acetaminophen, meloxicam, and buprenorphine to relieve pain associated with immunization with Freund's adjuvant concluded that these analgesics alleviated behavior associated with pain without decreasing the antibody response [16]. In that study, mice were immunized once with protective antigen (PA) and Freund's complete adjuvant and twice with PA and Freund's incomplete adjuvant but the functional activity of the antiserum over time, such as a toxin neutralization assay, was not performed. We noted here that there was no measured effect in ascites $\mathrm{mAb}$ fluid production in the meloxicam, buprenorphine, or meloxicam and buprenorphine group when compared to the control group from the second collection of ascites.

Measuring pain in prey species is particularly difficult and methods of accurately assessing pain are still being developed. Cage side observations are our facility's primary means of assessing pain. The development of intervention scoresheets based on the input of veterinarians and scientists are employed regularly. There is still much debate on the point that mice used in ascites production begin to experience pain and it is reported to vary based on the volume of pristane injected, number of hybridoma cells injected, frequency and method of abdominal paracentesis, and hybridoma growth characteristics $[1,7,8]$. It was unknown at what point the mice injected with this particular hybridoma cell line would become painful. The mice appeared and acted normally until a significant amount of ascites was present, at which time an increased respiratory rate was seen in some animals and reduced grooming was seen in others. This is consistent with what has been reported in the literature $[7,8]$. Some compare ascites antibody production to a condition similar to peritonitis [1]. Peritonitis is considered a severely painful condition that should be treated with multimodal analgesia $[12,17,18]$. Group D received both meloxicam and buprenorphine (multimodal analgesia) upon the recognition of pain. No effects on quantity or quality of antibodies collected were observed utilizing this multimodal analgesic approach compared to the other groups and therefore the combination will be the analgesic treatment of choice at the prescribed doses for mice used with this hybridoma cell line in the future. The effectiveness of the pain management was not assessed as the study was not designed as such; however, the effectiveness of pain management and the utilization of preemptive analgesia should be further investigated.

\section{Conclusion}

In vitro techniques should be utilized when possible to replace ascites production in mice unless scientifically justified. However, for studies that must use mice, efforts to refine the procedure by reducing the pain and distress experienced by the animals should be used. Analgesics may be administered upon recognition of pain in mice with no effect on antibody concentration or quality for studies involving producing $\mathrm{mAb} 2 \mathrm{~F} 9$ as demonstrated here. Preemptive analgesia and the effectiveness of the analgesia should be considered in future antibody production studies and further investigated. 


\section{Abbreviations}

mAb: Monoclonal antibody

ADE: Antibody dependent enhancement.

\section{Conflict of Interests}

The authors declare that there is no conflict of interests regarding the publication of this paper.

\section{Authors' Contribution}

Shannon T. Marko and Stephen F. Little contributed equally to this work.

\section{Acknowledgments}

Opinions, interpretations, conclusions, and recommendations are those of the authors and not necessarily endorsed by the US Army or Department of Defense. The authors thank Krystal Bean and Emily Bailey for their editorial review. Additionally, The authors thank Steve Kern and Sarah Norris for their statistical analysis and review.

\section{References}

[1] Institute for Laboratory Animal Research, Monoclonal Antibody Production, Institute for Laboratory Animal Research, Washington, DC, USA, 1999.

[2] B. R. Brodeur, P. Tsang, and Y. Larose, "Parameters affecting ascites tumour formation in mice and monoclonal antibody production," Journal of Immunological Methods, vol. 71, no. 2, pp. 265-272, 1984.

[3] C. F. M. Hendriksen and W. De Leeuw, "Production of monoclonal antibodies by the ascites method in laboratory animals," Research in Immunology, vol. 149, no. 6, pp. 535-542, 1998.

[4] H. L. Amyx, "Control of animal pain and distress in antibody production and infectious disease studies," Journal of the American Veterinary Medical Association, vol. 191, no. 10, pp. 1287$1289,1987$.

[5] J. M. Moore and T. V. Rajan, "Pristane retards clearance of particulate materials from the peritoneal cavity of laboratory mice," Journal of Immunological Methods, vol. 173, no. 2, pp. 273278,1994

[6] L. R. Jackson, L. J. Trudel, J. G. Fox, and N. S. Lipman, "Monoclonal antibody production in murine ascites II. Production characteristics," Laboratory Animal Science, vol. 49, no. 1, pp. 8186, 1999.

[7] L. R. Jackson, L. J. Trudel, J. G. Fox, and N. S. Lipman, "Monoclonal antibody production in murine ascites I. Clinical and pathologic features," Laboratory Animal Science, vol. 49, no. 1, pp. 70-80, 1999.

[8] N. C. Peterson, "Behavioral, clinical, and physiologic analysis of mice used for ascites monoclonal antibody production," Comparative Medicine, vol. 50, no. 5, pp. 516-526, 2000.

[9] N. C. Peterson and J. E. Peavey, "Comparison of in vitro monoclonal antibody production methods with an in vivo ascites production technique," Contemporary Topics in Laboratory Animal Science, vol. 37, no. 5, pp. 61-66, 1998.
[10] M. Potter, J. S. Wax, A. O. Anderson, and R. P. Nordan, "Inhibition of plasmacytoma development in BALB/c mice by indomethacin," Journal of Experimental Medicine, vol. 161, no. 5, pp. 996-1012, 1985.

[11] F. E. Piersma, M. A. R. C. Daemen, A. E. J. M. Vd Bogaard, and W. A. Buurman, "Interference of pain control employing opioids in in vivo immunological experiments," Laboratory Animals, vol. 33, no. 4, pp. 328-333, 1999.

[12] A. Z. Karas, P. J. Dannenman, and J. M. Cadillac, "Strategies for assessing and minimizing pain," in Anesthesia and Analgesia in Laboratory Animals, R. E. Fish, M. J. Brown, P. J. Danneman, and A. Z. Kara, Eds., pp. 195-218, Academies Press, San Diego, Calif, USA, 2nd edition, 2008.

[13] B. Rouveix, "Opiates and immune function. Consequences on infectious diseases with special reference to AIDS," Therapie, vol. 47 , no. 6 , pp. 503-512, 1992.

[14] E. P. Ryan, S. J. Pollack, T. I. Murant, S. H. Bernstein, R. E. Felgar, and R. P. Phipps, "Activated human B lymphocytes express cyclooxygenase- 2 and cyclooxygenase inhibitors attenuate antibody production," Journal of Immunology, vol. 174, no. 5, pp. 2619-2626, 2005.

[15] E. Shacter, G. K. Arzadon, and J. Williams, "Elevation of interleukin- 6 in response to a chronic inflammatory stimulus in mice: inhibition by indomethacin," Blood, vol. 80, no. 1, pp. 194-202, 1992.

[16] A. M. Kolstad, R. M. Rodriguiz, C. J. Kim, and L. P. Hale, "Effect of pain management on immunization efficacy in mice," Journal of the American Association for Laboratory Animal Science, vol. 51, pp. 488-457, 2012.

[17] D. J. Gaertner, T. M. Hallman, F. C. Hankenson, and M. A. Batchelder, "Anesthesia and analgesia for laboratory rodents," in Anesthesia and Analgesia in Laboratory Animals, R. E. Fish, M. J. Brown, P. J. Danneman, and A. Z. Karas, Eds., pp. 239-297, Academies Press, San Diego, Calif, USA, 2nd edition, 2008.

[18] Institute for Laboratory Animal Research, Recognition and Alleviation of Pain in Laboratory Animals, Washington, DC, USA, 2009.

[19] S. F. Little, S. H. Leppla, and E. Cora, "Production and characterization of monoclonal antibodies to the protective antigen component of Bacillus anthracis toxin," Infection and Immunity, vol. 56, pp. 1807-1813, 1988.

[20] N. Mohamed, J. Li, C. S. Ferreira et al., "Enhancement of anthrax lethal toxin cytotoxicity: a subset of monoclonal antibodies against protective antigen increases lethal toxin-mediated killing of murine macrophages," Infection and Immunity, vol. 72, no. 6, pp. 3276-3283, 2004.

[21] S. F. Little, W. M. Webster, and D. E. Fisher, "Monoclonal antibodies directed against protective antigen of Bacillus anthracis enhance lethal toxin activity in vivo," FEMS Immunology and Medical Microbiology, vol. 62, no. 1, pp. 11-22, 2011.

[22] S. F. Little, W. M. Webster, S. L. W. Norris, and G. P. Andrews, "Evaluation of an anti-rPA IgG ELISA for measuring the antibody response in mice," Biologicals, vol. 32 , no. 2, pp. $62-$ 69, 2004.

[23] R. De Deken, J. Brandt, F. Ceulemans, S. Geerts, and R. Beudeker, "Influence of priming and inoculation dose on the production of monoclonal antibodies in two age groups of BALB/c mice," Hybridoma, vol. 13, no. 1, pp. 53-57, 1994. 
[24] S. Bancos, M. P. Bernard, D. J. Topham, and R. P. Phipps, "Ibuprofen and other widely used non-steroidal antiinflammatory drugs inhibit antibody production in human cells," Cellular Immunology, vol. 258, no. 1, pp. 18-28, 2009.

[25] R. Prymula, C.-A. Siegrist, R. Chlibek et al., "Effect of prophylactic paracetamol administration at time of vaccination on febrile reactions and antibody responses in children: two openlabel, randomised controlled trials," The Lancet, vol. 374, no. 9698, pp. 1339-1350, 2009. 


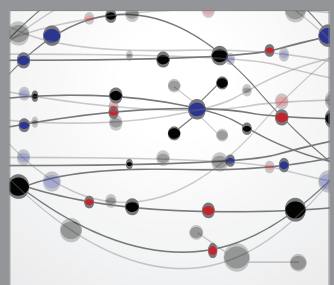

The Scientific World Journal
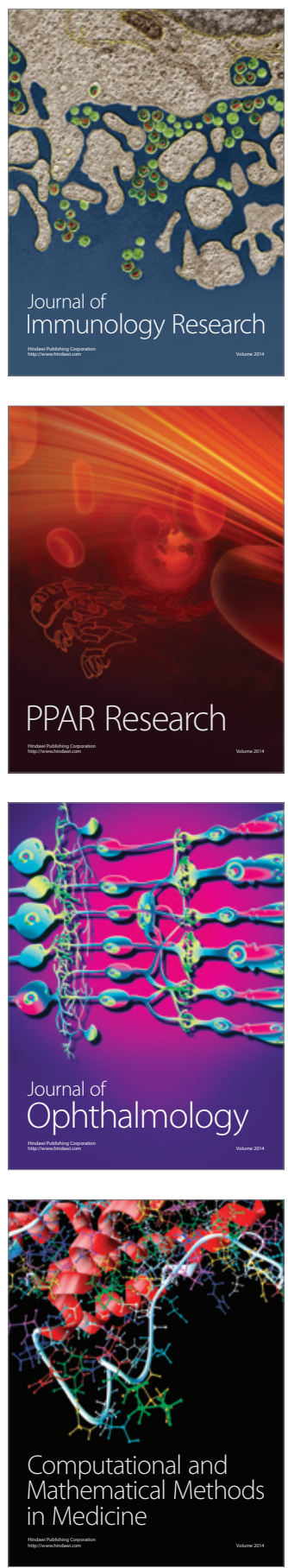

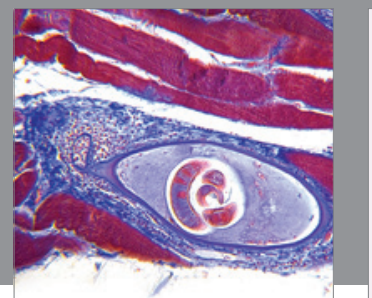

Gastroenterology

Research and Practice
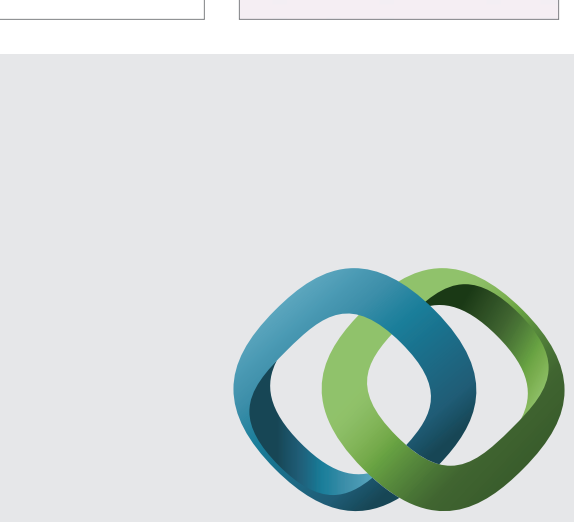

\section{Hindawi}

Submit your manuscripts at

http://www.hindawi.com
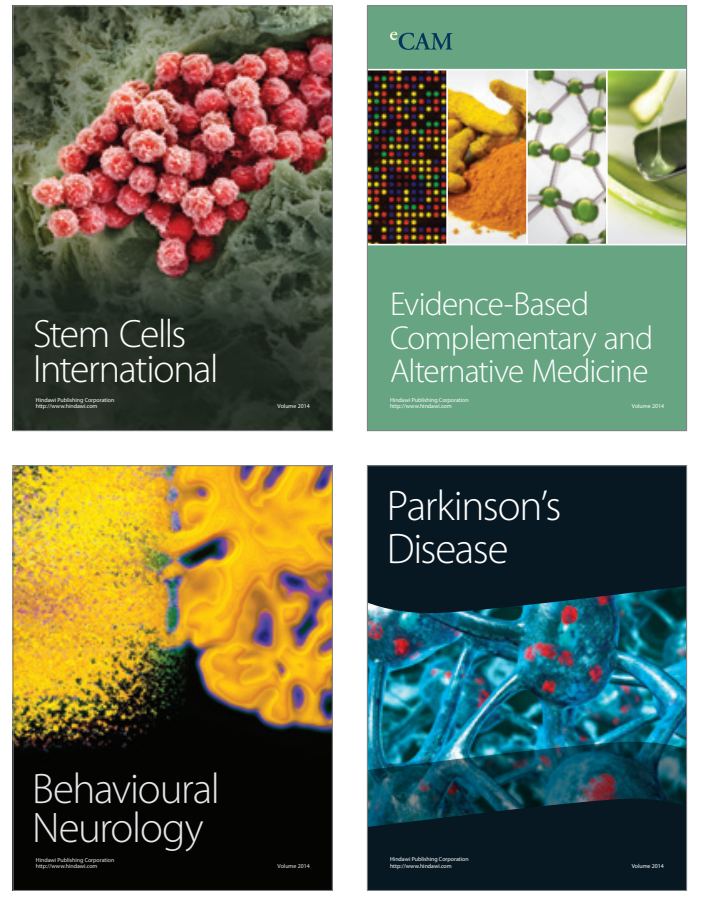
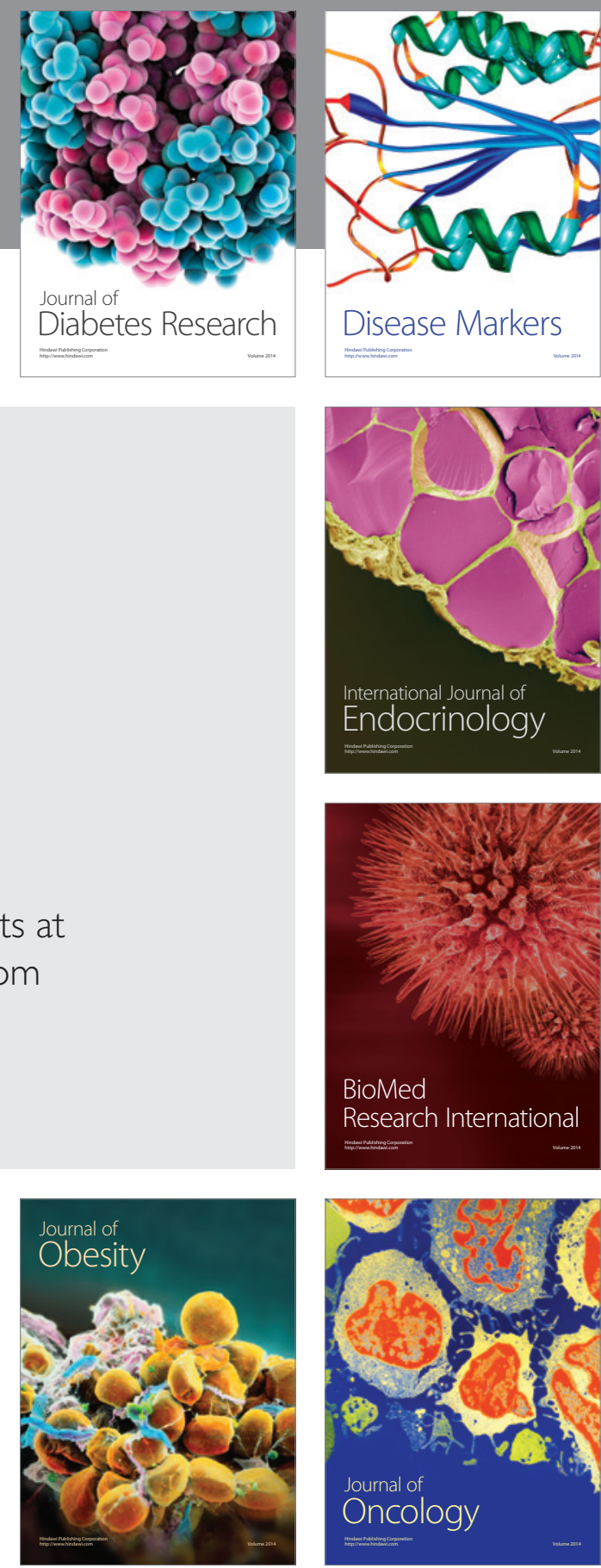

Disease Markers
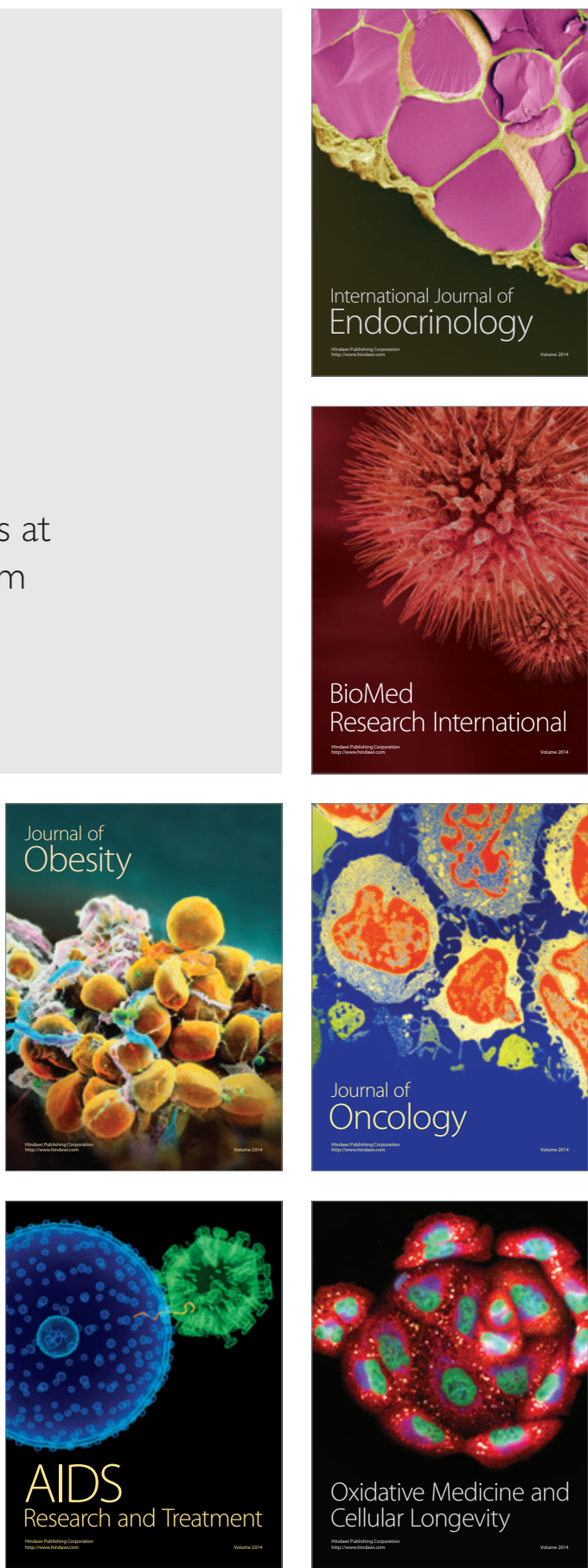